Afr. J. Trad. CAM (2006) 3 (3): 59 - 69

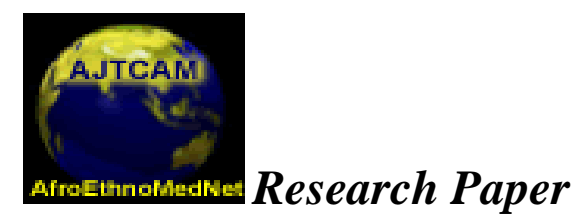

ISSN 0189-6016@2006
Afr. J. Traditional,

Complementary and

Alternative Medicines

www.africanethnomedicines.net

\title{
ANTIMICROBIAL AND BRINE SHRIMP LETHALITY OF EXTRACTS OF TERMINALIA MOLLIS LAWS
}

Mainen J. Moshi*, Zakaria H. Mbwambo, Modest C. Kapingu, Viva H. Mhozya, Chacha Marwa

Institute of Traditional Medicine, Muhimbili University College of Health Sciences, P.O.Box 65001, Dar es salaam, Tanzania.

E-mail: mmoshi@muchs.ac.tz Tel: 25522 2150096; Fax:255 222150465

\begin{abstract}
Using the disc diffusion method it was demonstrated that extracts of the leaves, stem and roots of Terminalia mollis Laws (Combretaceae) have antibacterial activity against Staphylococcus aureus (NCTC 6571), Escherichia coli (NCTC 10418), Pseudomonas aeruginosa (NCTC 10662), Klebsiella pneumoniae (NCTC 9633), Salmonella typhi (NCTC 8385), and Bacillus anthracis (NCTC 10073) and antifungal activity against Candida albicans (Strain HG 392), and local strains of Aspergillus flavus and Cryptococcus neoformans. The root extracts were the most active followed by the stem, and leaf extracts. Extracts of the three parts also exhibited cytotoxicity to brine shrimp larvae with $\mathrm{LC}_{50}$ values ranging from 26.3 to 58.1, 10.4 to 69.5, and 42.9$101.3 \mu \mathrm{g} / \mathrm{ml}$, for the root, stem, and leaf extracts, respectively. The results support the traditional uses of extracts of this plant for the management of bacterial and fungal infections.
\end{abstract}

Key words: Terminalia mollis, Antimicrobial activity, Traditional medicine.

\section{Introduction}

The family Combretaceae consists of 18 genera, the largest of which is Combretum with about 370 species, and Terminalia with about 200 species (McGaw et al., 2001). Plant species from the two genera, especially Combretum are widely used in traditional medicine throughout Africa (Kokwaro, 1993; Baba-Mousa et al., 1999; McGaw et al., 2001; Fyhrquist et al., 2002; 2004; Moshi and Mbwambo, 2005). 
Recent studies on the genus Terminalia have generated reports of useful biological activities, including antimicrobial (Katerere et al., 2002; Carpano et al., 2003; Bonjar, 2004a,b; Fyhrquist et al., 2002; 2004; Masoko et al., 2005; Moshi and Mbwambo, 2005), antidiabetic (Kaur et al., 2003), anti-HIV (Martino et al., 2002), antioxidant (Cheng et al., 2003), anticancer (Saleem et al., 2002), promotion of wound healing (Mukherjee et al., 2003), antimalarial (Sanon et al., 2003), anti-Herpes simplex type 2 (Cheng et al., 2002), and antidiarrhoeal activity (Abdullah et al., 2001), to mention a few. A number of the already established biological activities indicate the potential this genus has in the management of conditions associated with the HIV infection. Having recognized this potential, efforts are now ongoing to study the antimicrobial activities of Combretaceae plants that grow in Tanzania and are used in traditional medicine (Fyhrquist et al., 2002; 2004; Moshi and Mbwambo, 2005).

In the present study we are reporting work that was done on Terminalia mollis Laws (Combretaceae) (Syn:Terminalia tolurosa F. Hoffm., or Terminalia spekei Rolfe). This is a savanna woodlands tree $11-26 \mathrm{~m}$ tall, with a black gray, deep fissured bark (Dale and Greenway, 1961). It is widely used in Tanzania for the treatment of malaria and as an adjunct therapy for HIV patients, to treat diarrhea and bacterial infections. In Bukoba (northwestern Tanzania) where it is known as "Muongora" it has similar traditional uses as the related species Terminalia sericea Burch. Ex. DC., whose antimicrobial activity was recently reported (Moshi and Mbwambo, 2005). There is up to now very scanty information about this plant in the literature. One study in west Africa reported the molluscicidal activity of a root bark extract (Sofowora, 1980), and another reported that a 50\% aqueous ethanol extract of both the leaf and root bark have antifungal activity against Trichophyton mentagrophytes (MIC $0.25 \mathrm{mg} / \mathrm{ml}$ ), and Epidermophyton floccosum (MIC $0.5 \mathrm{mg} / \mathrm{ml}$ ), but did not show activity against Microsporum gypseum and Candida albicans (Baba-mousa et al., 1999). A recent study reported the presence of antifungal activity in different extracts of the leaves (Masoko et al., 2005). The current study explores further the antibacterial and antifungal activities of parts of the plant, and has included test for cytotoxicity, using brine shrimps (Meyer et al., 1982).

\section{Materials and Methods}

Materials

Petroleum ether, dichloromethane, ethyl acetate, butanol, and ethanol were purchased from Fisher Scientific, UK, Ltd (Bishop Meadow Road, Loughborough, Leicestershire, LE 11 5RG, UK). Saboraud's dextrose agar (SDA) and Mueller Hinton agar were purchased from Oxoid Ltd (Basingstoke, Hampshire, England), while dimethylsulfoxide (DMSO) was purchased from Sigma (Poole, Dorset, England). Brine shrimp eggs were bought from Dohse Acquaristic, Bonn (Aus Dem Hause Dohse Acquaristik), Germany. Sea salt was prepared locally by evaporating water collected from the Indian Ocean, along the Dar es Salaam Coast.

\section{Collection of plant material}

The plant was first collected in 1999 from Tabora and identified by Mr. Selemani of Botany Department, University of Dar es Salaam (voucher no. IMPP 
Afr. J. Trad. CAM (2006) 3 (3): 59- 69

002-0067). The material for this study was collected in Kagera region and identified by the same person (Voucher no. ZHM 2). Both vouchers are kept in the Herbarium of the Institute of Traditional Medicine, Muhimbili University College of Health Sciences.

\section{Extraction procedure}

The stem and whole roots of Terminalia mollis were separately chopped into small pieces, and ground into fine particles. The fine particles of the stem $(854.0 \mathrm{~g})$ and roots $(753.0 \mathrm{~g})$ were sequentially extracted with petroleum ether (5.0 1), ethylacetate (5.0 1), 1:1 mixture of dichloromethane/methanol (2.5 1 each), methanol (5.0 1), and distilled water (5.0 1). The aqueous eluent (3.8 1) was concentrated in vacuo at $30^{\circ} \mathrm{C}$ to $1.0 \mathrm{l}$. The later was twice partitioned with $500 \mathrm{ml}$ butanol. Solvents were completely dried in vacuo, and freeze dried to afford butanol and water extracts, respectively. The extract yields were (stem, roots) as follows: Petroleum ether (2.0; 2.4), Ethylacetate $(8.6 ; 11.0), 1: 1$ dichloromethane: methanol $(225.0 ; 22.0)$, methanol $(21.0 ; 200.0)$, butanol $(2.0 ; 23.6)$, aqueous $(1.0 ; 9.8) \mathrm{g}$, respectively. The leaves were dried in the shade and $825 \mathrm{~g}$ extracted by different solvents to afford extracts of petroleum ether (42 g), 1:1methanol:dichloromethane (52 g), Methanol (49 g), butanol (42 g), and water (50 g).

\section{Antimicrobial tests}

Antibacterial and antifungal activities were tested by the disc-diffusion method (Singh et al, 2002). Six standard bacteria, Staphylococcus aureus (NCTC 6571), Escherichia coli (NCTC 10418), Pseudomonas aeruginosa (NCTC 10662), Klebsiella pneumoniae (NCTC 9633), Salmonella typhi (NCTC 8385), and Bacillus anthracis (NCTC 10073) and the fungi, Candida albicans (Strain HG 392), and local strains of Aspergillus niger, Aspergillus fumigatus, Aspergillus flavus, Cryptococcus neoformans and Penicillium Spp.were used. Filter paper discs (Whatman No. 1; $5 \mathrm{~mm}$ diameter) were impregnated with crude extracts $(5 \mathrm{mg} / \mathrm{disc})$ or standard drugs $(20 \mu \mathrm{g} / \mathrm{disc}$ ampicillin, $10 \mu \mathrm{g} /$ disc gentamicin; for bacteria) and clotrimazole ( $20 \mu \mathrm{g} / \mathrm{disc}$; for fungi). The discs were overlayed on Mueller Hinton agar plates (for bacteria) and Saborauld's dextrose agar plates (for fungi) and incubated at $37^{\circ} \mathrm{C}$, for $24 \mathrm{~h}$ in the case of bacteria and Candida and for $48 \mathrm{~h}$ in the case of the other fungi. The discs were tested in triplicate, including one with a solvent blank and 3 for the standard drugs. Inhibition zones were calculated as the difference between disc diameter (5 $\mathrm{mm}$ ) and the diameters of inhibition (Hewitt and Vincent, 1989). The mean inhibition zones were used to calculate the activity index. Activity index (AI) was calculated as the mean inhibition zone for test sample divided by the mean inhibition zone for the standard drug (Singh et al, 2002). 
Afr. J. Trad. CAM (2006) 3 (3): 59- 69

\section{Brine shrimp lethality test}

The brine shrimp lethality test (BST) was used to predict the presence, in the extracts, of cytotoxic activity (Meyer et al., 1982). Assay procedures and analysis of results was done as reported earlier (Moshi and Mbwambo, 2005).

\section{Results}

\section{Antimicrobial activity}

Tables 1-3 show that extracts of the root, stem and leaves of Terminalia mollis exhibited antibacterial and antifungal activity. With the exception of the stem petroleum ether extract which exhibited antifungal activity against Cryptococcus neoformans, all the petroleum ether extracts had no activity against bacteria and fungi. Butanol, dichloromethane: methanol (1:1), and aqueous extracts exhibited antifungal activity against Candida albicans and Cryptococcus neoformans. The highest activity against Candida albicans was found in the stem extracts, while root extracts showed the highest activity against Cryptococcus neoformans. The aqueous extract exhibited the highest activity against both Candida albicans and Cryptococcus neoformans for all the three plant parts. All the stem extracts were inactive against Aspergillus species and the Penicillium species (Table 1).

Root extracts (Table 2) exhibited the best antibacterial and antifungal activity. Most of the root extracts, except petroleum ether, were active against all the bacteria used and three fungi, Candida albicans, Cryptococcus neoformans and Aspergillus flavus. The leaf ethylacetate, methanol, butanol and dichloromethane: methanol (1:1) extracts were active against Salmonella typhi, Staphylococcus aureus, and Bacillus anthracis (Table 3). They had no activity against Escherichia coli, Vibrio cholera and Pseudomonas aeruginosa. The aqueous extract was active against Staphylococcus aureus and Pseudomonas aeruginosa.

\section{Brine shrimp lethality}

Tables 4-6 showed results of the activity of the root, stem and leaf extracts against brine shrimp larvae, respectively. The butanol extract of the stem wood with an $\mathrm{LC}_{50}(95 \%$ confidence interval) of $10.4(5.9-18.3) \mu \mathrm{g} / \mathrm{ml}$ was the most toxic. The $\mathrm{LC}_{50}$ of the butanol extract of the stem was lower than that of the standard drug cyclophosphamide which gave an LC 50 of $16.3(10.6-25.2) \mu \mathrm{g} / \mathrm{ml}$. The stem extracts gave LC50 values between $35.0(18.3-66.9)$ and $69.5(51.9-93.1) \mu \mathrm{g} / \mathrm{ml}$. The root extracts gave $\mathrm{LC}_{50}(95 \%$ confidence interval) values between 26.3 (18.8-37.0) and 58.1 (43.9-76.8) $\mu \mathrm{g} / \mathrm{ml}$. The leaf extracts were less toxic to brine shrimps. The aqueous, methanol, and petroleum ether extracts gave LC 50 (95\% confidence interval) values between 42.5 (29.1-62.0) and $101.3(69.8-146.8) \mu \mathrm{g} / \mathrm{ml}$. 
Table 1: Antibacterial and antifungal activity of Terminalia mollis stem wood extracts

\begin{tabular}{|c|c|c|c|c|c|c|c|c|c|c|}
\hline Organisms tested on & & $\mathbf{P E}$ & ET & $\mathbf{M}$ & Bu & 1:1 M:D & AQ & $\begin{array}{l}\text { Clotr } \\
20 \mu g / \text { disc }\end{array}$ & $\begin{array}{l}\text { Gent } \\
10 \mu \mathrm{g} / \text { disc }\end{array}$ & $\begin{array}{l}\text { Amp } \\
20 \mu \mathrm{g} / \text { disc }\end{array}$ \\
\hline Escherichia coli & $\begin{array}{l}\mathrm{IZ} \\
\mathrm{AI}\end{array}$ & - & - & - & - & - & - & - & - & $\begin{array}{l}21.0 \pm 1.0 \\
1.0\end{array}$ \\
\hline Salmonella typhi & $\begin{array}{l}\mathrm{IZ} \\
\mathrm{AI}\end{array}$ & - & $\begin{array}{c}4.7 \pm 0.6 \\
0.2\end{array}$ & $\begin{array}{c}7.0 \pm 0 \\
0.3\end{array}$ & $\begin{array}{l}7.0 \pm 0 \\
0.3\end{array}$ & $\begin{array}{l}6.7 \pm 0.5 \\
0.3\end{array}$ & - & - & - & $\begin{array}{l}20.0 \pm 1.0 \\
1.0\end{array}$ \\
\hline Vibrio cholera & $\begin{array}{l}\mathrm{IZ} \\
\mathrm{AI}\end{array}$ & - & - & - & - & - & - & - & - & $\begin{array}{l}17.0 \pm 1.0 \\
1.0\end{array}$ \\
\hline $\begin{array}{l}\text { Staphylococcus } \\
\text { aureus }\end{array}$ & $\begin{array}{l}\mathrm{IZ} \\
\mathrm{AI}\end{array}$ & - & $\begin{array}{c}4.7 \pm 1.0 \\
0.2\end{array}$ & $\begin{array}{c}8.3 \pm 1.0 \\
0.4\end{array}$ & $\begin{array}{l}12.7 \pm 0.6 \\
0.6\end{array}$ & $\begin{array}{l}5.7 \pm 0.6 \\
0.3\end{array}$ & $\begin{array}{l}11.7 \pm 1.1 \\
0.6\end{array}$ & - & - & $\begin{array}{l}20.0 \pm 1.0 \\
1.0\end{array}$ \\
\hline Bacillus anthracis & $\begin{array}{l}\mathrm{IZ} \\
\mathrm{AI}\end{array}$ & - & $\begin{array}{c}6.7 \pm 0.6 \\
0.7\end{array}$ & $\begin{array}{c}5.0 \pm 0.6 \\
0.5\end{array}$ & $\begin{array}{c}5.3 \pm 0.6 \\
0.5\end{array}$ & $\begin{array}{l}5.3 \pm 1.0 \\
0.5\end{array}$ & - & - & - & $\begin{array}{l}10.3 \pm 1.5 \\
1.0\end{array}$ \\
\hline $\begin{array}{l}\text { Pseudomonas } \\
\text { aeruginosa }\end{array}$ & $\begin{array}{l}\mathrm{IZ} \\
\mathrm{AI}\end{array}$ & - & - & - & $\begin{array}{c}10.0 \pm 0 \\
0.8\end{array}$ & - & $\begin{array}{c}9.7 \pm 0.6 \\
0.8\end{array}$ & - & $\begin{array}{l}12.0 \pm 1.0 \\
1.0\end{array}$ & - \\
\hline Candida albicans & $\begin{array}{l}\mathrm{IZ} \\
\mathrm{AI}\end{array}$ & - & $\begin{array}{c}13.3 \pm 0.6 \\
0.9\end{array}$ & $\begin{array}{l}15.0 \pm 1.0 \\
1.0\end{array}$ & $\begin{array}{c}9.0 \pm 1.0 \\
0.6\end{array}$ & $\begin{array}{c}15.0 \pm 0 \\
1.0\end{array}$ & $\begin{array}{c}10.0 \pm 0 \\
0.7\end{array}$ & $\begin{array}{l}15.0 \pm 1.0 \\
1.0\end{array}$ & & \\
\hline Aspergillus niger & $\begin{array}{l}\mathrm{IZ} \\
\mathrm{AI}\end{array}$ & - & - & - & - & - & - & $\begin{array}{c}15.0 \pm 1.0 \\
1.0\end{array}$ & & \\
\hline Aspergillus fumigatus & $\begin{array}{l}\mathrm{IZ} \\
\mathrm{AI}\end{array}$ & - & - & - & - & - & - & $\begin{array}{c}25.0 \pm 1.0 \\
1.0\end{array}$ & & \\
\hline Aspergillus flavus & $\begin{array}{l}\mathrm{IZ} \\
\mathrm{AI}\end{array}$ & - & & & - & - & - & $20.0 \pm 0.6 \quad 1.00$ & & \\
\hline Cryptococcus & $\mathrm{IZ}$ & $1.3 \pm 0.6$ & $7.0 \pm 1.0$ & $5.3 \pm 0.6$ & $5.0 \pm 1.0$ & $5.7 \pm 0.6 \quad 0.3$ & $6.7 \pm 1.1$ & $15.0 \pm 1.0$ & & \\
\hline neoformans & AI & 0.1 & 0.5 & 0.3 & 0.3 & & 0.4 & 1.0 & & \\
\hline Penicillium spp. & $\begin{array}{l}\mathrm{IZ} \\
\mathrm{AI}\end{array}$ & - & - & - & - & - & - & $20.0 \pm 1.01 .0$ & & \\
\hline
\end{tabular}

Results are reported as inhibition zones $(\mathrm{IZ} ; \mathrm{mm})$ with the corresponding activity index $(\mathrm{AI})$. Inhibition zones are presented as mean $\pm \mathrm{SD}(\mathrm{n}=3)$. Inhibition zones (IZ) exclude the disc diameter $(5 \mathrm{~mm})$; Activity index $(\mathrm{AI})=$ Inhibition zone of test sample divided by inhibition zone of a standard drug. $\mathrm{B}=$ butanol extract; $\mathrm{AQ}=$ Aqueous extract; $\mathrm{M}=$ methanol extract; $\mathrm{Amp}=$ ampicillin; $\mathrm{D}=$ dichloromethane; $\mathrm{ET}=\mathrm{Ethyl}$ acetate; $\mathrm{P}=$ petroleum ether;.clotr $=$ clotrimazole 
Table 2: Antibacterial and antifungal activities of Terminalia mollis root extracts Organisms tested
M
Bu
1:1 M:D

IZ

AQ

$\begin{array}{ll}\text { Clotr } & \text { Gent } \\ 20 \mu \mathrm{g} / \mathrm{disc} & 10 \mu \mathrm{g} / \mathrm{disc}\end{array}$

Amp AI

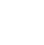

$20 \mu g / d$

$10 \mu \mathrm{g} /$ disc

$20 \mathrm{\mu g} / \mathrm{disc}$

Staphylococcus aureus

$\begin{array}{llc}\mathrm{IZ} & - & 19.3 \pm 0.7 \\ \mathrm{AI} & & 1.3 \\ \mathrm{IZ} & - & 11.0 \pm 1.0 \\ \mathrm{AI} & & 0.5 \\ \mathrm{IZ} & - & 13.7 \pm 0.6 \\ \mathrm{AI} & & 0.9 \\ \mathrm{IZ} & - & 11.0 \pm 0.6\end{array}$

$19.3 \pm 0.61 .3$

$20.0 \pm 1.01 .3$

$14.7 \pm 0.6 \quad 1.0$

$10.0 \pm 0$

Escherichia coli

$17.7 \pm 1.1$

$15.7 \pm 2.5$

$\begin{array}{ll}0.8 & 0.7\end{array}$

Pseudomonas aeruginosa

$20.0 \pm 1.0 \quad 1.3 \quad 19.3 \pm 0.7$

$8.0 \pm 1.0$

0.

0.7

Salmonella typhi

IZ - $11.0 \pm 0.6 \quad 0.5$

$19.7 \pm 0.6$

$16.0 \pm 0$

$1.2 \quad 12.7 \pm 0.6$

0.8

Vibrio cholera

$\begin{array}{llll}\text { AI } & & & \\ \text { IZ } & 12.0 \pm 1.0 & 1.0\end{array}$

1.0

$13.3 \pm 1.1 \quad 0.7$

$4 \quad 12.3 \pm 1.1$

0.6

$14.0 \pm 1.0 \quad 0.9$

$-$

$15.0 \pm 1.0$

1.0

$21.0 \pm 1.0$

$14.0 \pm 1.0 \quad 0.7 \quad-$

$11.0 \pm 1.00 .9$

$11.3 \pm 1.10 .9$

Bacillus anthracis

Candida albicans

IZ

$12.5 \pm 1.1$

$\begin{array}{ccc} & & 1.2 \\ 1.1 & 15.7 \pm 0.6 & 15.7 \pm 1.0\end{array}$

$15.0 \pm 0$

$\begin{array}{lll}1.6 & 1.6 & 1.5\end{array}$

$-9.7 \pm 0.6$

$14.0 \pm 1.9 \quad 0.7 \quad 7.0 \pm 1.0$

$12.3 \pm 0.6$

0.4

$17.3 \pm 2.5 \quad 1.7 \quad-$

$11.7 \pm 1.5 \quad 20.0 \pm 0$

0.6

1.0

Aspergillus niger

AI $\quad$ - -

Aspergillus fumigatus

Aspergillus flavus

AI - -

Aspergillus flavus

Cryptococcus neoformans

IZ - $10.0 \pm 1.0$

$-$

-

$-$

$-$

Penicillim spp

$3 \pm 0.6$

Mucor ssp.

$\begin{array}{ccc}16.0 \pm 1.0 & 15.8 \pm 2.08 & 15.0 \pm 1.0 \\ 0.8 & 0.8 & 0.7 \\ 9.7 \pm 0.6 & 2.0 \pm 1.0 & 10.0 \pm 0 \\ 0.5 & 0.1 & 0.5 \\ - & - & 5.0 \pm 1.0 \\ & & 0.2 \\ & & 5.3 \pm 0.6 \\ & & 0.3\end{array}$

1.0

$\begin{array}{ll}- & 25.0 \pm 1.0\end{array}$

$\begin{array}{ll}- & 1.0 \\ & 20.0 \pm 0\end{array}$

$13.0 \pm 0 \quad 0.6$

1.0

$20.0 \pm 1.0 \quad 1.0$ -

$\begin{array}{lc}- & 20.0 \pm 1.0 \\ 8.7 \pm 1.1 & 1.00 \\ & 20.0 \pm 1.0\end{array}$

1.0

Results are reported as inhibition zones $(\mathrm{IZ} ; \mathrm{mm})$ with the corresponding activity index $(\mathrm{AI})$. Inhibition zones are presented as mean \pm SD $(\mathrm{n}=3)$. Inhibition zones (IZ) exclude the disc diameter (5 mm); Activity index (AI) = Inhibition zone of test sample divided by inhibition zone of a standard drug. B = butanol extract; $\mathrm{AQ}=$ Aqueous extract; $\mathrm{M}=$ methanol extract; Amp=ampicillin; $\mathrm{D}=$ dichloromethane; ET = Ethyl acetate; $\mathrm{P}=$ petroleum ether; clotr = clotrimazole 
Afr. J. Trad. CAM (2006) 3 (3): $59-69$

Table 3: Antibacterial and antifungal activities of Terminalia mollis leaf extracts

\begin{tabular}{|c|c|c|c|c|c|c|c|c|c|}
\hline $\begin{array}{c}\text { Organisms } \\
\text { tested }\end{array}$ & $\begin{array}{l}\mathrm{IZ} \\
\mathrm{AI}\end{array}$ & $\mathbf{P E}$ & $\mathbf{M}$ & Bu & $\begin{array}{l}\text { 1:1 } \\
\text { M:D }\end{array}$ & $\mathbf{A Q}$ & $\begin{array}{l}\text { Clotr } \\
20 \\
\mu \mathrm{g} / \text { disc }\end{array}$ & $\begin{array}{l}\text { Gent } \\
10 \\
\mu \mathrm{g} / \text { disc }\end{array}$ & $\begin{array}{l}\text { Amp } \\
20 \\
\mu \mathrm{g} / \text { disc }\end{array}$ \\
\hline $\begin{array}{l}\text { Staphylococcus } \\
\text { aureus }\end{array}$ & $\begin{array}{l}\mathrm{IZ} \\
\mathrm{AI}\end{array}$ & - & - & - & $\begin{array}{l}13.3 \pm 2.9 \\
0.7\end{array}$ & $\begin{array}{l}16.3 \pm 1.5 \\
0.9\end{array}$ & - & - & $\begin{array}{l}20.0 \pm 1.1 \\
1.0\end{array}$ \\
\hline Escherichia coli & $\begin{array}{l}\mathrm{IZ} \\
\mathrm{AI}\end{array}$ & - & - & $\begin{array}{l}13.7 \pm 1.1 \\
0.7\end{array}$ & - & - & - & - & $\begin{array}{l}20.0 \pm 1.1 \\
1.0\end{array}$ \\
\hline $\begin{array}{l}\text { Pseudomonas } \\
\text { aeruginosa }\end{array}$ & $\begin{array}{l}\mathrm{IZ} \\
\mathrm{AI}\end{array}$ & - & - & - & - & - & - & $\begin{array}{l}15.0 \pm 1.15 \\
1.0\end{array}$ & - \\
\hline $\begin{array}{l}\text { Salmonella } \\
\text { typhi }\end{array}$ & $\begin{array}{l}\mathrm{IZ} \\
\mathrm{AI}\end{array}$ & - & - & - & $\begin{array}{l}5.3 \pm 0.6 \\
0.5\end{array}$ & - & - & $\begin{array}{l}10.0 \pm 0.6 \\
1.0\end{array}$ & - \\
\hline Shigella & $\begin{array}{l}\mathrm{IZ} \\
\mathrm{AI}\end{array}$ & & - & - & - & - & - & $\begin{array}{l}10.0 \pm 0 \\
1.0\end{array}$ & - \\
\hline $\begin{array}{l}\text { Klebsiella } \\
\text { Pneumoniae }\end{array}$ & & & - & - & - & - & - & $\begin{array}{l}10.0 \pm 1.0 \\
1.0\end{array}$ & - \\
\hline Vibrio cholera & $\begin{array}{l}\mathrm{IZ} \\
\mathrm{AI}\end{array}$ & - & - & - & ND & - & - & - & $\begin{array}{l}12.0 \pm 0.6 \\
1.0\end{array}$ \\
\hline $\begin{array}{l}\text { Bacillus } \\
\text { anthracis }\end{array}$ & $\begin{array}{l}\mathrm{IZ} \\
\mathrm{AI}\end{array}$ & - & - & $\begin{array}{l}2.3 \pm 0.6 \\
0.1\end{array}$ & - & $\begin{array}{l}5.3 \pm 1.1 \\
0.3\end{array}$ & - & - & $\begin{array}{l}20.0 \pm 0.6 \\
1.0\end{array}$ \\
\hline $\begin{array}{l}\text { Candida } \\
\text { albicans }\end{array}$ & $\begin{array}{l}\mathrm{IZ} \\
\mathrm{AI}\end{array}$ & _ & - & $\begin{array}{l}7.7 \pm 0.6 \\
0.2\end{array}$ & $\begin{array}{l}6.7 \pm 2.9 \\
0.2\end{array}$ & $\begin{array}{l}15.0 \pm 0 \\
0.5\end{array}$ & $\begin{array}{l}30.0 \pm 1.0 \\
1.0\end{array}$ & - & - \\
\hline $\begin{array}{l}\text { Aspergillus } \\
\text { fumigatus }\end{array}$ & $\begin{array}{l}\mathrm{IZ} \\
\mathrm{AI}\end{array}$ & - & - & $\begin{array}{l}4.0 \pm 1.0 \\
0.1\end{array}$ & - & - & $\begin{array}{l}30.0 \pm 0.6 \\
1.0\end{array}$ & - & - \\
\hline $\begin{array}{l}\text { Aspergillus } \\
\text { niger }\end{array}$ & $\begin{array}{l}\mathrm{IZ} \\
\mathrm{AI}\end{array}$ & & ND & ND & ND & - & $\begin{array}{l}15.0 \pm 1.0 \\
1.0\end{array}$ & - & - \\
\hline $\begin{array}{l}\text { Aspergillus } \\
\text { flavus }\end{array}$ & $\begin{array}{l}\mathrm{IZ} \\
\mathrm{AI}\end{array}$ & & ND & ND & ND & - & $\begin{array}{l}20.0 \pm 1.0 \\
1.0\end{array}$ & - & - \\
\hline $\begin{array}{l}\text { Cryptococcus } \\
\text { neoformans }\end{array}$ & $\begin{array}{l}\mathrm{IZ} \\
\mathrm{AI}\end{array}$ & - & - & $\begin{array}{l}8.0 \pm 1.0 \\
0.3\end{array}$ & $\begin{array}{l}5.0 \pm 0 \\
0.2\end{array}$ & $\begin{array}{l}15.0 \pm 1.0 \\
0.5\end{array}$ & $\begin{array}{l}30.0 \pm 1.0 \\
1.0\end{array}$ & - & - \\
\hline
\end{tabular}

Results are reported as inhibition zones (IZ; mm) with the corresponding activity index (AI). Inhibition zones are presented as mean $\pm S D(n=3)$. Inhibition zones (IZ) exclude the disc diameter $(5 \mathrm{~mm})$; Activity index $(\mathrm{AI})=$ Inhibition zone of test sample divided by inhibition zone of a standard drug. $\mathrm{B}=$ butanol extract; $\mathrm{AQ}=$ Aqueous extract; $\mathrm{M}=$ methanol extract; Amp=ampicillin; $\mathrm{D}=$ dichloromethane; $\mathrm{ET}=$ Ethyl acetate; $\mathrm{P}=$ petroleum ether;. clotr = clotrimazole

\section{Discussion}

Recently the antimicrobial and cytotoxic activities of extracts of Terminalia sericea roots, which shares similar ethnomedical uses with Terminalia mollis, were reported (Moshi and Mbwambo, 2005). They are both used in the treatment of diarrhea in HIV patients, and in addition Terminalia mollis is used in the treatment of malaria. 
Afr. J. Trad. CAM (2006) 3 (3): 59- 69

Table 4: Brine shrimp lethality of Terminalia mollis root extracts.

$\begin{array}{lll}\text { Extract type } & \mathbf{L C}_{\mathbf{5 0}} \mathbf{\mu g} / \mathbf{m l} & \mathbf{9 5 \%} \mathbf{C I s} \\ \text { Petroleum ether extract } & 26.3 & 18.8-37.0 \\ \text { Ethyl acetate extract } & 51.0 & 39.0-66.9 \\ \text { Dichloromethane:methanol extract (1:1) } & 58.1 & 43.9-76.8 \\ \text { Methanol extract } & 34.0 & 23.9-48.3 \\ \text { Butanol extract } & 29.2 & 20.9-40.9 \\ \text { Aqueous extract } & 35.2 & 26.3-47.2\end{array}$

The results are reported as $\mathrm{LC}_{50}$ values in $\mu \mathrm{g} / \mathrm{ml}$ with the corresponding $95 \%$ confidence intervals (95\% CI).

Table 5: Brine shrimp lethality of Terminalia mollis stem wood extracts.

$\begin{array}{lll}\text { Extract type } & \mathbf{L C}_{\mathbf{5 0}} \mathbf{~} \mathbf{g} / \mathbf{m l} & \mathbf{9 5 \%} \mathbf{C I} \\ \text { Pet ether extract } & 35.0 & 18.3-66.9 \\ \text { Ethylacetate extract } & 69.5 & 51.9-93.1 \\ \text { Butanol extract } & 10.4 & 5.9-18.3 \\ \text { Dichloromethane:methanol extract (1:1) } & 35.6 & 26.0-48.8 \\ \text { Methanol extract } & 49.7 & 38.1-65.0 \\ \text { Aqueous extract } & 54.9 & 42.6-70.8\end{array}$

The results are reported as $\mathrm{LC}_{50}$ values in $\mu \mathrm{g} / \mathrm{ml}$ with the corresponding $95 \%$ confidence intervals $(95 \% \mathrm{CI})$

Diarrhoea can be caused by different agents, including bacteria, fungi, and some protozoa. Bacteria that may cause diarrhea include Escherichia coli, Salmonella typi, and Vibrio cholera, while for fungi Candida albicans is responsible. Extracts of the roots were effective against bacteria and fungi that may cause diarrhea thus supporting the traditional uses for this purpose. The extracts were also effective against other important fungi like Cryptococcus neoformans, which is a fungus of importance in HIV patients as it is causes Cryptococcal meningitis. The results of this study are in agreement with those from another study which reported that leaf extracts of the plant have antifungal activity (Masoko et al., 2005). 
Afr. J. Trad. CAM (2006) 3 (3): $59-69$

Table 6: Brine shrimp lethality of Terminalia mollis leaf extracts.

$\begin{array}{lll}\text { Extract type } & \mathbf{L C}_{\mathbf{5 0}} \mathbf{\mu g} / \mathbf{m l} & \mathbf{9 5 \%} \mathbf{C I} \\ \text { Petroleum ether extract } & 93.5 & 64.9-134.6 \\ \text { Dichloromethane:methanol extract (1:1) } & 42.9 & 31.7-57.9 \\ \text { Methanol extract } & 101.2 & 69.8-146.8 \\ \text { Butanol extract } & 42.5 & 29.1-62.0 \\ \text { Aqueous extract } & 101.3 & 71.4-143.9\end{array}$

The results are reported as $\mathrm{LC}_{50}$ values in $\mu \mathrm{g} / \mathrm{ml}$ with the corresponding $95 \%$ confidence intervals $(95 \% \mathrm{CI})$.

Using the microdilution method they detected antifungal activity in all the extracts, polar and non-polar, unlike in this in which the petroleum ether extracts were largely inactive against both bacteria and fungi.

Plants of the Combretaceae family are known to be sources for combretastins (Rogers and Verotta, 1996), which have potent anticancer activity. However, given the low predictive nature of the brine shrimps test that was used in this study it is difficult to directly relate the high toxicity with the presence, in the extracts, of activity with useful anticancer compounds. At best we can only speculate about this possibility as has been indicated before (Meyer et al., 1982). The petroleum ether extracts of the roots and stem exhibited high toxicity on brine shrimps, but hardly did they exhibit antibacterial and antifungal activity. This may indicate selectivity, although with the disc diffusion method there could be problems of diffusion through the agar by non-polar extracts hence failure to detect zone of inhibition. It is however, noteworthy mentioning that the petroleum ether extract was dissolved in DMSO, so the solution would not have difficulty to diffuse through the agar.

In conclusion, the detection of antibacterial and antifungal activity in extracts of T. mollis supports the traditional uses of this plant for the treatment of bacterial and fungal infections. The brine shrimp results suggest need for follow up with tests on cancer cell lines. 


\section{Acknowledgement}

We are most grateful to the NAPRALERT data base of the University of Illinois, at Chicago, for allowing us access to literature. This work was supported by the Tanzania Commission for AIDS which administers the Multilateral AIDS funds for the Tanzanian government.

\section{References}

1. Abdullahi, A.L., Agho, M.O., Amos, S., Gamaniel, K.S., Wambebe, C. (2001). Antidiarrhoeal activity of the aqueous extract of Terminalia avicennoides roots. Phytother. Res. 15:431-434.

2. Baba-moussa, F., Akpagana, K., Bouchet, P. (1999). Antifungal activities of seven West African Combretaceae used in traditional medicine. J. Ethnopharmacol. 66:335-338.

3. Bonjar, G.H. (2004a). Antibacterial screening of plants used in Iranian folkloric medicine. Fitoter. 75:231-5.

4. Bonjar, G.H. (2004b). Inhibition of Clotrimazole-resistant Candida albicans by plants used in Iranian folkloric medicine. Fitoter. 75:74-6.

5. Carpano, S.M., Spegazzini, E.D., Rossi, J.S., Castro, M.T., Debenedetti, S.L. (2003). Antifungal activity of Terminalia australis. Fitoter. 74:294-7.

6. Cheng, H.Y., Lin, C.C., Lin, T.C. (2002). Antiherpes simplex virus type 2 activity of casuarinin from the bark of Terminalia arjuna Linn. Antivir. Res. 55:447-55.

7. Cheng, H.Y., Lin, T.C., Yu, K.H., Yang, C.M., Lin, C.C. (2003). Antioxidant and free radical scavenging activities of Terminalia chebula. Biological and Pharmaceut. Bulletin 26:1331-5.

8. Dale, I.R. and Greenway, P.J. (1961). In Kenya trees \& shrubs. Nairobi, Buchanan's Kenya Estates, Pp. 152-3.

9. Fyhrquist, P., Mwasumbi, L., Haeggstrom, C.A., Vuorela, H., Hiltunen, R., Vuorela, P. (2002). Ethnobotanical and antimicrobial investigation on some species of Terminalia and Combretum (Combretaceae) growing in Tanzania. J. Ethnopharmacol. 79:169-77.

10. Fyhrquist, P., Mwasumbi, L., Haeggstrom, C.A., Vuorela, H., Hiltunen, R., Vuorela, P., (2004). Antifungal activity of selected species of Terminalia, Pteleopsis and Combretum (Combretaceae) in Tanzania. Pharmaceut. Biol. 42: 308317.

11. Hewitt, W. and Vincent, S. (1989). In: Theory and application of microbiological assay. Academic Press, San Diego, p. 39.

12. Katerere, D.R., Gray, A.I., Nash, R.J., Waigh, R.D. (2003). Antimicrobial activity of pentacyclic triterpenes isolated from African Combretaceae. Phytochem. 63:818.

13. Kaur, S., Arora, S., Kaur, S., Kumar, S. (2003). Bioassay-guided isolation of antimutagenic factors from fruits of Terminalia bellerica. J. Environ. Pathol. Toxicol. Oncol. 22:69-76.

14. Kokwaro, O. (1993). Medicinal plants of East Africa. East African Literature Bureau, Nairobi. Pp. 68-69. 
15. Masoko, P., Picard, J., Eloff, J.N. (2005). Antifungal activities of six South African Terminalia species (Combretaceae). J. Ethnopharmacol. 99:301-308.

16. Martino, V.S., Lopez, P., Martinez Irujo, J.J., Sanroman, M., Cuevas, M.T., Santiago, E., Lasarte, J.J., Font, M., Coussio, J.D., Monge, A. (2002). Inhibitory effect against polymerase and ribonuclease activities of HIV-reverse transcriptase of the aqueous leaf extract of Terminalia triflora. Phytother. Res. 16:778-80.

17. McGaw, L.J., Rabe, T., Sparg, S.G., Jäger, A.K., Eloff, J.NB., van Staden, J. (2001). An investigation on the biological activity of Combretum species. J. Ethnopharmacol. 75:45-50.

18. Meyer, B.N., Ferrigini, R.N., Jacobsen, L.B., Nicholas, D.E., MC Laughlin, J.L. (1982). Brine shrimp: a convenient general bioassay for active plant constituents. Planta Med. 45:31-35.

19. Moshi, M.J. and Mbwambo, Z.H. (2005). Some pharmacological properties of extracts of Terminalia sericea roots. J. Ethnopharmacol. 97:43-47.

20. Mukherjee, P.K., Mukherjee, K., Rajesh Kumar, M., Pal, M., Saha, B.P. (2003). Evaluation of wound healing activity of some herbal formulations. Phytother. Res. 17:265-8.

21. Rogers, C.B. and Verotta, L. (1996). Chemistry and biological properties of the African Combretaceae. In: Hostettman, K., Chinyanganya, F., Maillard, M., Wolfender, J.L. (Eds), Chemistry, Biological and Pharmacological Properties of African Medicinal Plants, University of Zimbabwe Publications, Harare, Zimbabwe, p 121-141.

22. Saleem, A., Husheem, M., Harkonen, P., Pihlaja, K. (2002). Inhibition of cancer cell growth by crude extract and the phenolics of Terminalia chebula retz. fruit. J. Ethnopharmacol. 81:327-36.

23. Sanon, S., Ollivier, E., Azas, N., Mahiou, V., Gasquet, M., Ouattara, C.T., Nebie, I., Traore E. F., Balansard, G., Timon-David, P., Fumoux, F. (2003). Ethnobotanical survey and in vitro antiplasmodial activity of plants used in traditional medicine in Burkina Faso. J. Ethnopharmacol. 86:143-147.

24. Singh, B., Sahu, P.M., Sharma, M.K. (2002). Anti-inflammatory and Antimicrobial activities of triterpenoids from Strobilanthes callosus Nees. Phytomed. 9:355-359.

25. Sofowora, E.A. and Adewunmi, C.O. (1980). Preliminary screening of some plant extracts for molluscicidal activity. Planta Med. 39:57-65. 